\title{
Phycicoccus jejuensis gen. nov., sp. nov., an actinomycete isolated from seaweed
}

\author{
Soon Dong Lee
}

Correspondence

Soon Dong Lee

sdlee@cheju.ac.kr
Department of Science Education, Cheju National University, Jeju 690-756, Republic of Korea

A marine actinomycete strain, designated $\mathrm{KSW} 2-15^{\top}$, was isolated from a dried seaweed sample collected from a sandy beach on the coast of Jeju in the Republic of Korea. The organism produced non-motile, non-endospore-forming, Gram-positive, coccoid cells. The colonies were circular, translucent and yellow in colour with entire margins. meso-Diaminopimelic acid was present as the diamino acid of the peptidoglycan. The acyl type of the muramic acid was acetyl. Mycolic acids were not present. The predominant menaquinone was MK- $8\left(\mathrm{H}_{4}\right)$. The polar lipids were phosphatidylethanolamine, phosphatidylinositol and diphosphatidylglycerol. The major cellular fatty acids were of the saturated, unsaturated and iso-branched methyl types. The DNA G +C content was $74 \mathrm{~mol} \%$. Phylogenetic analyses based on $16 \mathrm{~S}$ rRNA gene sequences revealed that strain KSW2$15^{\top}$ formed a loose association with 'Candidatus Nostocoida limicola', within the radiation of the family Intrasporangiaceae of the suborder Micrococcineae. The organism showed the highest levels of sequence similarity with 'Candidatus Nostocoida limicola' (96.1\%), Terrabacter tumescens (96.1\%) and Terrabacter terrae (96.0\%). The levels of $16 \mathrm{~S}$ rRNA gene sequence similarity between the isolate and members of other genera of the family Intrasporangiaceae were in the range $92 \cdot 1-95 \cdot 5 \%$. On the basis of the polyphasic evidence, the isolate should be classified within a novel genus and species, for which the name Phycicoccus jejuensis gen. nov., sp. nov. is proposed. The type strain of Phycicoccus jejuensis is strain KSW2-15 $\left(=\mathrm{KCCM} 42315^{\top}=\right.$ NRRL B$\left.24460^{\top}\right)$.
The family Intrasporangiaceae Rainey et al. 1997 emend. Stackebrandt \& Schumann 2000 (Stackebrandt et al., 1997; Stackebrandt \& Schumann, 2000) currently includes 11 genera with validly published names and can be divided into three groups according to the isomer and the kind of diamino acid in the peptidoglycan. The group possessing LL-diaminopimelic acid (DAP) in the peptidoglycan contains four genera: Arsenicicoccus (Collins et al., 2004), Intrasporangium (Kalakoutskii et al., 1967), Terrabacter (Collins et al., 1989) and Terracoccus (Prauser et al., 1997). Members of the second group have L-ornithine in the cell wall; this group contains three genera, namely Ornithinicoccus (Groth et al., 1999), Ornithinimicrobium (Groth et al., 2001) and Serinicoccus (Yi et al., 2004). Only four genera in the family, Janibacter (Martin et al., 1997), Knoellia (Groth et al., 2002), Oryzihumus (Kageyama et al., 2005) and Tetrasphaera (Maszenan et al., 2000), have both meso-DAP in the peptidoglycan and $\mathrm{MK}-8\left(\mathrm{H}_{4}\right)$ as the major menaquinone, but these genera can be readily distinguished on the basis of other phenotypic characteristics (Martin

Abbreviation: DAP, diaminopimelic acid.

The GenBank/EMBL/DDBJ accession number for the 16S rRNA gene sequence of strain $\mathrm{KSW} 2-15^{\top}$ is DQ345443. et al., 1997; Maszenan et al., 2000; Hanada et al., 2002; Groth et al., 2002; Kageyama et al., 2005).

During the course of studying marine bacteria sampled from the coast of Jeju in the Republic of Korea, a yellowpigmented actinomycete, strain KSW2-15 ${ }^{\mathrm{T}}$, was isolated from a dried seaweed sample collected at Gwakji beach and was subjected to polyphasic taxonomic characterization. For bacterial isolation, a piece of dried seaweed was directly transferred onto WAT agar plates (Li et al., 2002) supplemented with $60 \%(\mathrm{v} / \mathrm{v})$ sterilized natural seawater. This isolation medium (WAT-SW agar) consisted of $0.05 \%$ $\mathrm{MgSO}_{4} .7 \mathrm{H}_{2} \mathrm{O}, 0.05 \% \mathrm{CaCl}_{2} \cdot 2 \mathrm{H}_{2} \mathrm{O}$ and $1.5 \%$ agar in $60 \%$ natural seawater and $40 \%$ distilled water $(\mathrm{pH} 7 \cdot 3)$. A colony on the plate, incubated at $30{ }^{\circ} \mathrm{C}$ for 14 days, was subcultured on YE-SW medium $(0.4 \%$ yeast extract, $1 \cdot 0 \%$ malt extract, $0.4 \%$ glucose, $1 \cdot 8 \%$ agar, $60 \%$ natural seawater and $40 \%$ distilled water). The pure culture was maintained at -20 and $-80{ }^{\circ} \mathrm{C}$ in a $20 \%$ glycerol suspension supplemented with $60 \%$ natural seawater.

The DAP isomer, the cell-wall acyl type and the presence of mycolic acids were determined as described by Staneck \& Roberts (1974), Uchida \& Aida (1984) and Minnikin et al. (1980), respectively. Polar lipids and menaquinones were extracted by using the integrated procedure of Minnikin 
et al. (1984). Polar lipid profiles were determined by twodimensional TLC (Minnikin et al., 1977). Menaquinones were analysed by using HPLC (Kroppenstedt, 1985). For the above analyses, the organism was cultivated on YE-SW broth for 3 days at $30^{\circ} \mathrm{C}$ and harvested by centrifugation at 3000 r.p.m. for 20 min. Extraction of the cellular fatty acids and determination of the fatty acid composition were performed by gas chromatography performed according to the instructions of the Microbial Identification System (MIDI), using cells grown on trypticase soy agar (Difco) for 3 days at $30^{\circ} \mathrm{C}$. The DNA G + C content was determined by HPLC (Mesbah et al., 1989). The results of the chemotaxonomic analyses are given in the genus description. The fatty acid profile of the organism was characterized by the predominance of $\mathrm{C}_{17: 1} \omega 8 c(19 \cdot 4 \%)$, iso- $\mathrm{C}_{16: 0}(15 \cdot 1 \%)$, iso$\mathrm{C}_{15: 0}(13 \cdot 9 \%), \mathrm{C}_{15: 0}(9 \cdot 5 \%)$ and $\mathrm{C}_{17: 0}(8 \cdot 8 \%)$. Other fatty acids present at levels above at least $1 \%$ were iso- $\mathrm{C}_{14: 0}$ $(5 \cdot 3 \%)$, anteiso- $\mathrm{C}_{15: 0}(4 \cdot 8 \%), \mathrm{C}_{17: 0} 3-\mathrm{OH}(4 \cdot 5 \%), \mathrm{C}_{17: 0}$ 10-methyl (3.1\%), $\mathrm{C}_{16: 0}(2 \cdot 7 \%), \mathrm{C}_{12: 0}(2 \cdot 2 \%), \mathrm{C}_{18: 1} \omega 8 \mathrm{c}$ $(1 \cdot 9 \%)$, anteiso- $\mathrm{C}_{17: 0}(1 \cdot 8 \%)$ and $\mathrm{C}_{18: 0}(1 \cdot 1 \%)$.

The 16S rRNA gene sequence was determined as described elsewhere (Lee et al., 2000; Lee \& Jeong, 2006). Phylogenetic analyses were performed by using three tree-making algorithms, namely the neighbour-joining (Saitou \& Nei, 1987), maximum-likelihood (Felsenstein, 1981) and maximumparsimony (Fitch, 1971) methods on a multiple alignment matrix (Thompson et al., 1997). A neighbour-joining tree was reconstructed from evolutionary distances calculated using the Jukes-Cantor coefficient (Jukes \& Cantor, 1969). The tree topology was evaluated by means of a bootstrap analysis (Felsenstein, 1985) of 1000 replicated datasets. An almost-complete 16S rRNA gene sequence for strain KSW2- $15^{\mathrm{T}}$, containing a continuous stretch of $1413 \mathrm{nt}$, was compared with those of related organisms from the family Intrasporangiaceae. A total of 1259 unambiguous aligned positions present in all strains were used for phylogenetic analyses. A neighbour-joining tree (Fig. 1) based on $16 \mathrm{~S}$ rRNA gene sequences revealed that strain KSW2 $-15^{\mathrm{T}}$ was loosely associated with 'Candidatus Nostocoida limicola' within the radiation encompassing representatives of the family Intrasporangiaceae. This clustering, albeit with moderate bootstrap support ( $56 \%$ ), was also found in the trees obtained using maximum-likelihood and maximumparsimony methods. The highest levels of sequence similarity for the isolate occurred with 'Candidatus N. limicola' $(96 \cdot 1 \%)$, Terrabacter tumescens $(96 \cdot 1 \%)$ and Terrabacter terrae $(96.0 \%)$. The levels of $16 \mathrm{~S}$ rRNA gene sequence similarity between the isolate and other representatives of the family Intrasporangiaceae were in the range $92 \cdot 1-95 \cdot 5 \%$.

Colony pigmentation was observed visually and recorded after 7 days growth at $30^{\circ} \mathrm{C}$ on YE-SW agar. Colony morphology was observed using a stereoscan microscope. Cell morphology and motility were determined by using phase-contrast and transmission electron microscopy. Cells were grown on YE-SW medium, with/without agar supplementation, at $30^{\circ} \mathrm{C}$. Cells were harvested after 15 ,

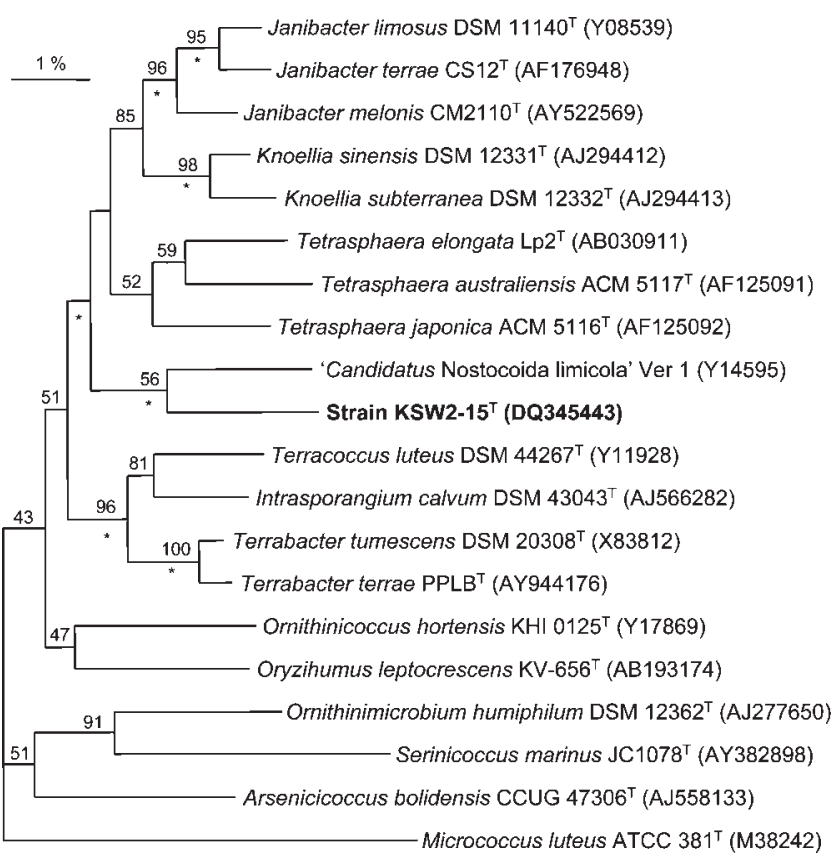

Fig. 1. Neighbour-joining tree showing the phylogenetic position of strain $\mathrm{KSW} 2-15^{\top}$ within the radiation encompassing related genera of the family Intrasporangiaceae. The tree was reconstructed from evolutionary distances calculated using the Jukes-Cantor coefficient. Asterisks indicate branches replicated with both the maximum-likelihood (Felsenstein, 1981) and maximum-parsimony (Fitch, 1971) tree-making algorithms. Numbers at nodes indicate percentages of bootstrap support based on a neighbour-joining analysis of 1000 resampled datasets (only values greater than $40 \%$ are indicated). Bar, 1 substitution per 100 nucleotides. 'Candidatus N. limicola' Ver 1 is described elsewhere in this issue as the type strain of Tetrasphaera veronensis (McKenzie et al., 2006).

24 and $48 \mathrm{~h}$ and subjected to microscopic examination. Oxidase activity was assessed from the oxidation of $N, N, N^{\prime}, N^{\prime}$-tetramethyl-p-phenylenediamine. Catalase activity was determined with a $3 \%(\mathrm{v} / \mathrm{v}) \mathrm{H}_{2} \mathrm{O}_{2}$ solution. Urease activity was determined from a colour change in Bacto urea broth (Difco). The temperature range for growth was determined by using YE-SW agar at $4-42{ }^{\circ} \mathrm{C}$. The $\mathrm{pH}$ range for growth was determined on YE-SW agar adjusted to $\mathrm{pH} 4 \cdot 1-10 \cdot 1$ (at intervals of $1 \cdot 0 \mathrm{pH}$ unit). $\mathrm{NaCl}$ tolerance for growth was studied on ISP 2 medium (Shirling \& Gottlieb, 1966) that contained $\mathrm{NaCl}$ at final concentrations of $0-9 \%(\mathrm{w} / \mathrm{v})$. The degradation of elastin was determined on ISP 2 medium supplemented with $0 \cdot 4 \%(\mathrm{w} / \mathrm{v})$ elastin. Nitrate reduction, the fermentation of glucose and the hydrolysis of aesculin, casein, gelatin and starch were examined by using methods described previously (MacFaddin, 1980). To test for DNA hydrolysis, cells were grown for 3 days at $30^{\circ} \mathrm{C}$ on DNase test agar (Difco) supplemented with methyl green. The ability of the isolate to utilize a broad range of substrates as sole carbon sources was tested using GP2 microplates (Microlog system; Biolog) 


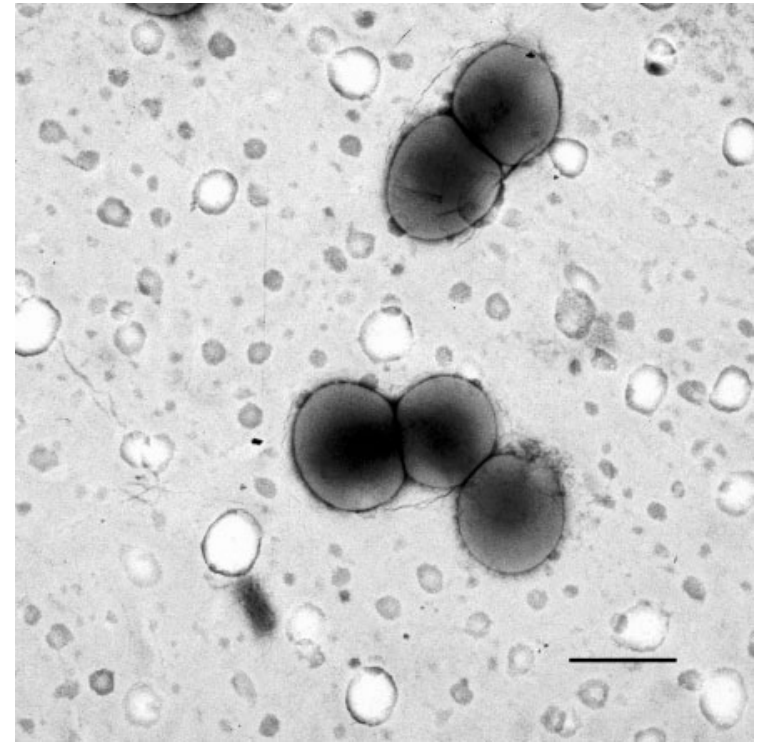

Fig. 2. Transmission electron micrograph of strain $\mathrm{KSW} 2-15^{\top}$ grown on YE-SW agar for $48 \mathrm{~h}$ at $30^{\circ} \mathrm{C}$. Bar, $1 \cdot 0 \mu \mathrm{m}$.

with 95 carbon-containing compounds. The cells were grown for $48 \mathrm{~h}$ at $30^{\circ} \mathrm{C}$ on tryptic soy broth agar and suspended in $2 \%(\mathrm{w} / \mathrm{v})$ sea salts solution (Sigma). After adjustment to $20 \%$ transmittance, $150 \mu \mathrm{l}$ suspension was transferred to each well, and the plates were incubated for $48 \mathrm{~h}$ at $30^{\circ} \mathrm{C}$. Reduction of tetrazolium violet was determined by reading the absorbance of the microtitre plates at $595 \mathrm{~nm}$ using a microplate reader. API ZYM strips (bioMérieux) were used according to the manufacturer's instructions, the inoculum having been prepared with cells grown on YE-SW agar at $30^{\circ} \mathrm{C}$ for 3 days. Strain KSW2-15 was found to be aerobic, non-motile, non-endosporeforming and Gram-positive. The cells were always cocci at all growth stages, irrespective of the physical condition of the medium, and occurred singly, in pairs, in short chains or in clusters (Fig. 2). Colonies were circular, smooth, convex and moderately yellow in colour with entire margins. The results of the physiological and biochemical tests are given in the species description.

In all of the phylogenetic trees, strain KSW2-15 ${ }^{\mathrm{T}}$ consistently formed a clade with strains of 'Candidatus N. limicola' (described as a filamentous bacterium isolated from activated sludge; Blackall et al., 2000). Because of the practical difficulty in obtaining biomass for polyphasic characterization, a validly published name was not given for this filamentous bacterium by Blackall et al. (2000) [note: three novel species of Tetrasphaera are proposed in this issue by McKenzie et al. (2006) for strains of 'Candidatus N. limicola']. Strain KSW2-15 ${ }^{\mathrm{T}}$ can be readily differentiated from 'Candidatus N. limicola' by the comparison of limited features, namely 16S rRNA gene sequence similarity and morphological characteristics (Blackall et al., 2000). Of the genera in the family Intrasporangiaceae, members of the genus Terrabacter showed high levels of $16 \mathrm{~S}$ rRNA gene sequence similarity $(96 \cdot 0-96 \cdot 1 \%)$ with respect to strain KSW2 $-15^{\mathrm{T}}$, albeit showing a loose association in the phylogenetic trees. It was evident, however, that they were chemotaxonomically different from our isolate in having LL-DAP as the principal diamino acid of the peptidoglycan and in the absence of unsaturated fatty acids (Collins et al., 1989; Martin et al., 1997; Montero-Barrientos et al., 2005). Four genera of the family Intrasporangiaceae - Janibacter (Martin et al., 1997), Knoellia (Groth et al., 2002), Oryzihumus (Kageyama et al., 2005) and Tetrasphaera (Maszenan et al., 2000) - contain meso-DAP as the principal cell-wall diamino acid and contain $\mathrm{MK}-8\left(\mathrm{H}_{4}\right)$ as the major menaquinone, but they could be distinguished from our isolate with reference to a combination of morphological and chemotaxonomic characteristics (Table 1) as well as phylogenetic distinctness.

On the basis of the phenotypic and phylogenetic data presented in this study, a novel genus and species are discribed for the isolate, for which the name Phycicoccus jejuensis gen. nov., sp. nov. is proposed.

\section{Description of Phycicoccus gen. nov.}

Phycicoccus (Phy.ci.coc'cus. L. n. phycos $-i$ from Gr. n. phukos seaweed; N.L. masc. n. coccus from Gr. n. kokkos a grain or berry; N.L. masc. n. Phycicoccus coccus from seaweed).

Gram-positive, oxidase-negative and catalase-positive. Cells are non-endospore-forming, non-motile and coccoid. Cells occur singly, in pairs, in short chains or in clusters. The diamino acid of the peptidoglycan is meso-DAP. The acyl type of the muramic acid is acetyl. Mycolic acids are not present. The predominant menaquinone is $\mathrm{MK}-8\left(\mathrm{H}_{4}\right)$. The phospholipid profile contains phosphatidylethanolamine, phosphatidylinositol and diphosphatidylglycerol (phospholipid type PII pattern). The predominant cellular fatty acids are $\mathrm{C}_{17: 1} \omega 8 c$, iso- $\mathrm{C}_{16: 0}$, iso- $\mathrm{C}_{15: 0}, \mathrm{C}_{15: 0}$ and $\mathrm{C}_{17: 0}$. The DNA G + C content is $74 \mathrm{~mol} \%$. Phylogenetically, the genus is loosely associated with genera of the family Intrasporangiaceae, suborder Micrococcineae. The type species of the genus is Phycicoccus jejuensis.

\section{Description of Phycicoccus jejuensis sp. nov.}

Phycicoccus jejuensis (je.ju.en'sis. N.L. masc. adj. jejuensis of Jeju, Republic of Korea, the site at which the type strain was isolated).

Aerobic, Gram-positive, non-motile, non-endospore-forming, oxidase-negative, catalase-positive. Cells are cocci that occur singly, in pairs, in short chains or in clusters. Colonies are circular, smooth, translucent and moderately yellow in colour. The chemotaxonomic characteristics are the same as those given in the genus description. Urease-negative. Nitrate is reduced to nitrite. Gelatin liquefaction is observed. Aesculin, casein, DNA and starch are hydrolysed. Elastin is 
Table 1. Phenotypic characteristics of strain $\mathrm{KSW} 2-15^{\top}$ and meso-DAP-containing members of the family Intrasporangiaceae

Data for reference genera were taken from Martin et al. (1997) (Janibacter), Groth et al. (2002) (Knoellia), Kageyama et al. (2005) (Oryzihumus) and Maszenan et al. (2000) and Hanada et al. (2002) (Tetrasphaera). The major menaquinone in all taxa is $\mathrm{MK}_{-8}\left(\mathrm{H}_{4}\right)$.

\begin{tabular}{|c|c|c|c|c|c|}
\hline Characteristic & Strain KSW2-15 & Janibacter & Knoellia & Oryzihumus & Tetrasphaera \\
\hline Cell morphology & Cocci & $\begin{array}{l}\text { Coccoid to } \\
\text { rod-shaped }\end{array}$ & $\begin{array}{l}\text { Coccoid to } \\
\text { rod-shaped }\end{array}$ & Irregular rods & $\begin{array}{c}\text { Cocci or irregular } \\
\text { rods }\end{array}$ \\
\hline Polar lipids ${ }^{*}$ & DPG, PE, PI & DPG, PG, PI & $\begin{array}{c}\text { DPG, PE, PI, } \\
\text { PG, PL }\end{array}$ & ND & $\begin{array}{c}\mathrm{DPG}, \mathrm{PG}, \mathrm{PI} \\
\mathrm{PE} \dagger, \mathrm{APL} \dagger, \mathrm{PL} \dagger\end{array}$ \\
\hline Fatty acid types $\ddagger$ & $\mathrm{S}, \mathrm{A}, \mathrm{I}, \mathrm{U}$ & $S, I, U$ & S, I, A & S, I, A & $\mathrm{S}, \mathrm{I}, \mathrm{A}, \mathrm{U} \dagger$ \\
\hline DNA $\mathrm{G}+\mathrm{C}$ content $(\mathrm{mol} \%)$ & 74 & 70 & $68-69$ & $72-73$ & $68-71$ \\
\hline Isolation source(s) & Dried seaweed & $\begin{array}{c}\text { Sludge, sewage } \\
\text { waste }\end{array}$ & Soil from cave & Paddy soil & $\begin{array}{c}\text { Sludge, sewage } \\
\text { waste }\end{array}$ \\
\hline
\end{tabular}

*APL, Unknown aminophospholipid; DPG, diphosphatidylglycerol; PE, phosphatidylethanolamine; PG, phosphatidylglycerol; PI, phosphatidylinositol; PL, unknown phospholipid(s); ND, not determined.

$†$ Component detected in only some representatives of the genus (Maszenan et al., 2000; Hanada et al., 2002).

¥A, Anteiso-methyl-branched; I, iso-methyl-branched; S, straight-chain saturated; U, monounsaturated.

degraded. Glucose fermentation does not occur. The temperature range for growth is $4-37^{\circ} \mathrm{C}$, with an optimum at $30{ }^{\circ} \mathrm{C}$. No growth occurs at $40{ }^{\circ} \mathrm{C}$. The $\mathrm{pH}$ for growth is in the range $\mathrm{pH} 5 \cdot 1-10 \cdot 1$, with an optimum of $\mathrm{pH} 7 \cdot 1$. Growth occurs in the presence of $0-7 \% \mathrm{NaCl}$. The following substrates are utilized as sole carbon and energy sources: dextrin, glycogen, mannan, Tweens 40 and 80, $\mathrm{N}$-acetyl-Dglucosamine, $N$-acetyl- $\beta$-D-mannosamine, amygdalin, Larabinose, D-arabitol, D-galacturonic acid, gentiobiose, D-gluconic acid, $\alpha$-D-glucose, myo-inositol, $\alpha$-D-lactose, lactulose, maltose, D-mannitol, D-mannose, D-melezitose, D-melibiose, methyl $\alpha$-D-galactoside, methyl $\beta$-D-galactoside, methyl $\alpha$-D-glucoside, methyl $\beta$-D-glucoside, methyl $\alpha$-D-mannoside, palatinose, D-psicose, D-raffinose, L-rhamnose, D-ribose, salicin, sedoheptulosan, D-sorbitol, stachyose, sucrose, D-tagatose, D-trehalose, turanose, xylitol, D-xylose, acetic acid, $\alpha$-, $\beta$ - and $\gamma$-hydroxybutyric acids, $p$ hydroxyphenylacetic acid, $\alpha$-ketoglutaric acid, $\alpha$-ketovaleric acid, lactamide, L-lactic acid, L-malic acid, propionic acid, succinamic acid, succinic acid, L-alaninamide, D- and Lalanine, L-alanyl glycine, L-asparagine, L-glutamic acid, glycyl L-glutamic acid, L-serine, putrescine, 2,3-butanediol, glycerol, adenosine, $2^{\prime}$-deoxyadenosine, inosine, thymidine, uridine, thymidine $5^{\prime}$-monophosphate, uridine $5^{\prime}$-monophosphate, D-fructose 6-phosphate, $\alpha$-D-glucose 1-phosphate, D-glucose 6-phosphate and DL- $\alpha$-glycerol phosphate. Utilization of the following substrates is weakly positive: inulin, arbutin, D-cellobiose, D-fructose, L-fucose, Dgalactose, maltotriose, 3-methyl D-glucoside, D-lactic acid methyl ester, monomethyl succinate, $N$-acetyl-L-glutamic acid, L-pyroglutamic acid and adenosine 5'-monophosphate. $\alpha$-Cyclodextrin, $\beta$-cyclodextrin, methylpyruvate and D-malic acid are not used as sole carbon and energy sources. Of the tests in the API ZYM system, alkaline phosphatase, esterase (C4), esterase lipase (C8), lipase (C14), leucine arylamidase, valine arylamidase, cystine arylamidase, trypsin, $\alpha$-chymotrypsin, acid phosphatase,
naphthol-AS-BI-phosphohydrolase, $\alpha$-galactosidase, $\beta$ galactosidase, $\alpha$-glucosidase and $\beta$-glucosidase are positive. Tests for $\beta$-glucuronidase, $N$-acetyl- $\beta$-glucosaminidase, $\alpha$ mannosidase and $\alpha$-fucosidase are negative. The predominant cellular fatty acids are $\mathrm{C}_{17: 1} \omega 8 c$, iso- $\mathrm{C}_{16: 0}$, iso- $\mathrm{C}_{15: 0}$, $\mathrm{C}_{15: 0}$ and $\mathrm{C}_{17: 0}$. The DNA $\mathrm{G}+\mathrm{C}$ content is $74 \mathrm{~mol} \%$.

The type strain, KSW2-15 $5^{\mathrm{T}}$ (= KCCM $42315^{\mathrm{T}}=$ NRRL B$24460^{\mathrm{T}}$ ), was isolated from dried seaweed on Gwakji beach on Jeju Island, Republic of Korea.

\section{Note added in proof}

Another new genus has been described in the Intrasporangiaceae (Kribbia dieselivorans gen. nov., sp. nov.; Jung et al., 2006), with the same diagnostic diamino acid, after this paper was accepted for publication.

\section{Acknowledgements}

This work was supported by the 21C Frontier Microbial Genomics and Application Center Program, Ministry of Science and Technology, Republic of Korea. The author is grateful to J. M. Lee for the isolation of the novel strain and to H. L. Yang for fatty acid analysis.

\section{References}

Blackall, L. L., Seviour, E. M., Bradford, D., Rossetti, S., Tandoi, V. \& Seviour, R. J. (2000). 'Candidatus Nostocoida limicola', a filamentous bacterium from activated sludge. Int J Syst Evol Microbiol 50, 703-709.

Collins, M. D., Dorsch, M. \& Stackebrandt, E. (1989). Transfer of Pimelobacter tumescens to Terrabacter gen. nov. as Terrabacter tumescens comb. nov. and of Pimelobacter jensenii to Nocardioides as Nocardioides jensenii comb. nov. Int J Syst Bacteriol 39, 1-6.

Collins, M. D., Routh, J., Saraswathy, A., Lawson, P. A., Schumann, P., Welinder-Olsson, C. \& Falsen, E. (2004). Arsenicicoccus bolidensis 
gen. nov., sp. nov., a novel actinomycete isolated from contaminated lake sediment. Int J Syst Evol Microbiol 54, 605-608.

Felsenstein, J. (1981). Evolutionary trees from DNA sequences: a maximum likelihood approach. J Mol Evol 17, 368-376.

Felsenstein, J. (1985). Confidence limits on phylogenies: an approach using the bootstrap. Evolution 39, 783-791.

Fitch, W. M. (1971). Towards defining the course of evolution: minimum change for a specific tree topology. Syst Zool 20, 406-416.

Groth, I., Schumann, P., Martin, K., Schuetze, B., Augsten, K., Kramer, I. \& Stackebrandt, E. (1999). Ornithinicoccus hortensis gen. nov., sp. nov., a soil actinomycete which contains L-ornithine. Int J Syst Bacteriol 49, 1717-1724.

Groth, I., Schumann, P., Weiss, N., Schuetze, B., Augsten, K. \& Stackebrandt, E. (2001). Ornithinimicrobium humiphilum gen. nov., sp. nov., a novel soil actinomycete with L-ornithine in the peptidoglycan. Int J Syst Evol Microbiol 51, 81-87.

Groth, I., Schumann, P., Schïtze, B., Augsten, K. \& Stackebrandt, E. (2002). Knoellia sinensis gen. nov., sp. nov. and Knoellia subterranea sp. nov., two novel actinobacteria isolated from a cave. Int J Syst Evol Microbiol 52, 77-84.

Hanada, S., Liu, W.-T., Shintani, T., Kamagata, Y. \& Nakamura, K. (2002). Tetrasphaera elongata sp. nov., a polyphosphate-accumulating bacterium isolated from activated sludge. Int J Syst Evol Microbiol 52, 883-887.

Jukes, T. H. \& Cantor, C. R. (1969). Evolution of protein molecules. In Mammalian Protein Metabolism, pp. 21-132. Edited by H. N. Munro. New York: Academic Press.

Jung, S.-Y., Kim, H.-S., Song, J. J., Lee, S.-G., Oh, T.-K. \& Yoon, J.-H. (2006). Kribbia dieselivorans gen. nov., sp. nov., a novel member of the family Intrasporangiaceae. Int J Syst Evol Microbiol 56, 2427-2432.

Kageyama, A., Takahashi, Y., Seki, T., Tomoda, H. \& Ōmura, S. (2005). Oryzihumus leptocrescens gen. nov., sp. nov. Int J Syst Evol Microbiol 55, 2555-2559.

Kalakoutskii, L. V., Kirillova, I. P. \& Krassilnikov, N. A. (1967). A new genus of the Actinomycetales - Intrasporangium gen. nov. J Gen Microbiol 48, 79-85.

Kroppenstedt, R. M. (1985). Fatty acid and menaquinone analysis of actinomycetes and related organisms. In Chemical Methods in Bacterial Systematics, pp. 173-199. Edited by M. Goodfellow \& D. E. Minnikin. London: Academic Press.

Lee, S. D. \& Jeong, H. S. (2006). Actinomadura hallensis sp. nov., a novel actinomycete isolated from Mt. Halla in Korea. Int J Syst Evol Microbiol 56, 259-264.

Lee, S. D., Kang, S.-O. \& Hah, Y. C. (2000). Hongia gen. nov., a new genus of the order Actinomycetales. Int J Syst Evol Microbiol 50, 191-199.

Li, Y.-Z., Hu, W., Zhang, Y.-Q., Qiu, Z.-J., Zhang, Y. \& Wu, B.-H. (2002). A simple method to isolate salt-tolerant myxobacteria from marine samples. J Microbiol Methods 50, 205-209.

MacFaddin, J. F. (1980). Biochemical Tests for Identification of Medical Bacteria, 2nd edn. Baltimore: Williams \& Wilkins.

Martin, K., Schumann, P., Rainey, F. A., Schuetze, B. \& Groth, I. (1997). Janibacter limosus gen. nov., sp. nov., a new actinomycete with meso-diaminopimelic acid in the cell wall. Int J Syst Bacteriol 47, 529-534.

Maszenan, A. M., Seviour, R. J., Patel, B. K. C., Schumann, P., Burghardt, J., Tokiwa, Y. \& Stratton, H. M. (2000). Three isolates of novel polyphosphate-accumulating Gram-positive cocci, obtained from activated sludge, belong to a new genus, Tetrasphaera gen. nov., and description of two new species, Tetrasphaera japonica sp. nov. and Tetrasphaera australiensis sp. nov. Int J Syst Evol Microbiol 50, 593-603.

McKenzie, C. M., Seviour, E. M., Schumann, P. \& 7 other authors (2006). Isolates of 'Candidatus Nostocoida limicola' Blackall et al. 2000 should be described as three novel species of the genus Tetrasphaera, as Tetrasphaera jenkinsii sp. nov., Tetrasphaera vanveenii sp. nov. and Tetrasphaera veronensis sp. nov. Int J Syst Evol Microbiol 56, 2279-2290.

Mesbah, M., Premachandran, U. \& Whitman, W. B. (1989). Precise measurement of the $\mathrm{G}+\mathrm{C}$ content of deoxyribonucleic acid by highperformance liquid chromatography. Int J Syst Bacteriol 39, 159-167.

Minnikin, D. E., Patel, P. V., Alshamaony, L. \& Goodfellow, M. (1977). Polar lipid composition in the classification of Nocardia and related bacteria. Int J Syst Bacteriol 27, 104-117.

Minnikin, D. E., Hutchinson, I. G., Caldicott, A. B. \& Goodfellow, M. (1980). Thin layer chromatography of methanolysates of mycolic acid-containing bacteria. J Chromatogr 188, 221-233.

Minnikin, D. E., O'Donnell, A. G., Goodfellow, M., Alderson, G., Athalye, M., Schaal, A. \& Parlett, J. H. (1984). An integrated procedure for the extraction of bacterial isoprenoid quinones and polar lipids. J Microbiol Methods 2, 233-241.

Montero-Barrientos, M., Rivas, R., Velazquez, E., Monte, E. \& Roig, M. G. (2005). Terrabacter terrae sp. nov., a novel actinomycete isolated from soil in Spain. Int J Syst Evol Microbiol 55, 2491-2495.

Prauser, H., Schumann, P., Rainey, F. A., Kroppenstedt, R. M. \& Stackebrandt, E. (1997). Terracoccus luteus gen. nov., sp. nov., an LL-diaminopimelic acid-containing coccoid actinomycete from soil. Int J Syst Bacteriol 47, 1218-1224.

Saitou, N. \& Nei, M. (1987). The neighbor-joining method: a new method for reconstructing phylogenetic trees. Mol Biol Evol 4, 406425.

Shirling, E. B. \& Gottlieb, D. (1966). Methods for characterization of Streptomyces species. Int J Syst Bacteriol 16, 313-340.

Stackebrandt, E. \& Schumann, P. (2000). Description of Bogoriellaceae fam. nov., Dermacoccaceae fam. nov., Rarobacteraceae fam. nov. and Sanguibacteraceae fam. nov. and emendation of some families of the suborder Micrococcineae. Int J Syst Evol Microbiol 50, 1279-1285.

Stackebrandt, E., Rainey, F. A. \& Ward-Rainey, N. L. (1997). Proposal for a new hierarchic classification system, Actinobacteria classis nov. Int J Syst Bacteriol 47, 479-491.

Staneck, J. L. \& Roberts, G. D. (1974). Simplified approach to identification of aerobic actinomycetes by thin-layer chromatography. Appl Microbiol 28, 226-231.

Thompson, J. D., Gibson, T. J., Plewniak, F., Jeanmougin, F. \& Higgins, D. G. (1997). The CLUSTAL $X$ windows interface: flexible strategies for multiple sequence alignment aided by quality analysis tools. Nucleic Acids Res 25, 4876-4882.

Uchida, K. \& Aida, K. (1984). An improved method for the glycolate test for simple identification of the acyl type of bacterial cell walls. $J$ Gen Appl Microbiol 30, 131-134.

Yi, H., Schumann, P., Sohn, K. \& Chun, J. (2004). Serinicoccus marinus gen. nov., sp. nov., a novel actinomycete with L-ornithine and L-serine in the peptidoglycan. Int J Syst Evol Microbiol 54, 1585-1589. 